F. Reprod. Fert. (1968) 16, 217-222

\title{
CHANGES IN THE REPRODUCTIVE ORGANS OF COLD-EXPOSED AND LIGHT-DEPRIVED FEMALE HAMSTERS (MESOCRICETUS AURATUS)
}

\author{
RUSSEL J. REITER \\ Department of Anatomy, University of Rochester Medical Center, \\ 260 Crittenden Boulevard, Rochester, New Tork
}

(Received 3rd Fuly 1967, revised 11 th Ociober 1967)

\begin{abstract}
Summary. After removal of the eyes or exposure to cold $\left(6^{\circ} \mathrm{C}\right)$ female golden hamsters had smaller uteri than controls. If animals were both blinded and cold-exposed the effects on the reproductive organs were additive. Removal of the pineal gland prevented uterine regression in light-deprived hamsters but did not delay or prevent the regressive response in cold-exposed animals. Although the ovaries of cold-exposed animals did not change in size, they displayed marked interstitial hypertrophy and had fewer follicular elements and corpora lutea. It is suggested that blinding and cold-exposure each induce a similar hormonal imbalance.
\end{abstract}

\section{INTRODUCTION}

Although in normal laboratory conditions the golden hamster is a polyoestrous animal (Kent, 1967), it probably hibernates and breeds seasonally in its natural habitat (Lyman, 1948; Eisentraut, 1952; Lyman \& Chatfield, 1955). Two possible inducers of these seasonal variations are environmental lighting and ambient temperature (Hafez, 1964). However, studies designed to determine the importance of photoperiod and temperature on influencing reproduction are few. The size and metabolic activity of the reproductive organs of adult albino rats and mice are relatively insensitive to darkness (Browman, 1937; Hoffmann, 1967) or cold (Hale, Mefferd, Vowter, Foerster \& Criscuolo, 1959; Baillie, 1961 ; Ewing, Brant \& Ebner, 1967), but this does not apply to the golden hamster. Lack of light, either in the form of short daily photoperiods or blinding, causes marked gonadal atrophy in both sexes (Hoffman \& Reiter, 1965a; Reiter, Hoffman \& Hester, 1966b). Hoffman, Hester \& Towns (1965) reported gonadal involution in cold-exposed hamsters, but only males were studied.

The photosensitivity of the hamster gonad is mediated through the sympathetic nervous system (Reiter \& Hester, 1966; Reiter, 1967a) and the pineal gland (Hoffman \& Reiter, 1965a; Reiter et al., 1966b). The following report deals with the action of the photoperiod and temperature, either alone or in combination, on the structure of the reproductive organs in female hamsters, and with the pineal gland as a possible mediator of these effects. 


\section{MATERIALS AND METHODS}

Groups of adult female hamsters (Mesocricetus auratus), weighing 75 to $90 \mathrm{~g}$, had either one (unilateral optic enucleation) or both (bilateral optic enucleation) eyes removed, were either pinealectomized or sham pinealectomized, and were kept either in cold $\left(6 \pm 1^{\circ} \mathrm{C}\right)$ or warm $\left(22 \pm 1^{\circ} \mathrm{C}\right)$ temperature-controlled rooms. Three or four animals were kept in each cage and the light/dark cycles in both rooms were maintained at $16 \mathrm{hr}$ of light and $8 \mathrm{hr}$ of darkness per 24-hr period. The methods used for pinealectomy (Hoffman \& Reiter, 1965b) and eye removal (Reiter \& Hester, 1966) have been described previously. Four groups of animals were studied at each temperature: (1) unilaterally enucleated, sham pinealectomized; (2) unilaterally enucleated, pinealectomized; (3) bilaterally enucleated, sham pinealectomized; and (4) bilaterally enucleated, pinealectomized animals. Half of each group from each room were killed 25 days after the beginning of the experiment, and the remainder were killed after 50 days exposure to the various regimens. One hundred and fifty-five hamsters were used for the investigation.

At death, the skull of each animal was opened and the area under the superior sagittal sinus was inspected either for pineal remnants or infection. The body weights as well as the weights of the ovaries and uteri were recorded. The organs were fixed in either Bouin's fluid or $10 \%$ neutral formalin. After routine processing, $8 \mu$-thick tissue sections were stained by the Movat (1955) technique or with haematoxylin and eosin.

\section{RESULTS}

The body weights of animals killed after either 25 or 50 days of treatment (Tables 1 and 2) were similar for all groups. Mean ovarian weights were not altered either by low temperature, blinding or pinealectomy.

Uteri of 25-day blinded animals (Table 1) with intact pineals and maintained at $22^{\circ} \mathrm{G}$ (Group 3 ) were smaller than those of similarly treated pinealectomized controls (Group 4). The ability of pineal removal to counteract the gonadal effects of blinding was expected (Reiter et al., 1966b). Pinealectomy of unilateral enucleated, warm-exposed hamsters did not alter uterine size (Group 2).

When blinded animals were kept in the cold the uteri averaged $139 \mathrm{mg} / 100 \mathrm{~g}$ body weight (Group 7); this is significantly less than the mean uterine weight of blinded, cold-exposed, pinealectomized animals (Group 8). However, the uteri of the latter were also significantly smaller than those of similarly treated animals kept in the warm room (Group 4). Hence, blinding and cold exposure independently caused changes in the pituitary-gonad axis of female hamsters, as reflected by uterine weights. The effects of light deprivation and low temperature were additive, but only one type of regression (that due to blinding) was prevented by removal of the pineal gland.

Although ovarian sizes were unchanged, the gonads of blinded and coldexposed animals were modified: there was a marked proliferation of the interstitial tissue, with a concomitant decrease in the number and size of the follicles. The most pronounced changes were seen in the ovaries of blinded, nonpinealectomized, cold-exposed hamsters (Group 7). 


\section{PLATE 1}

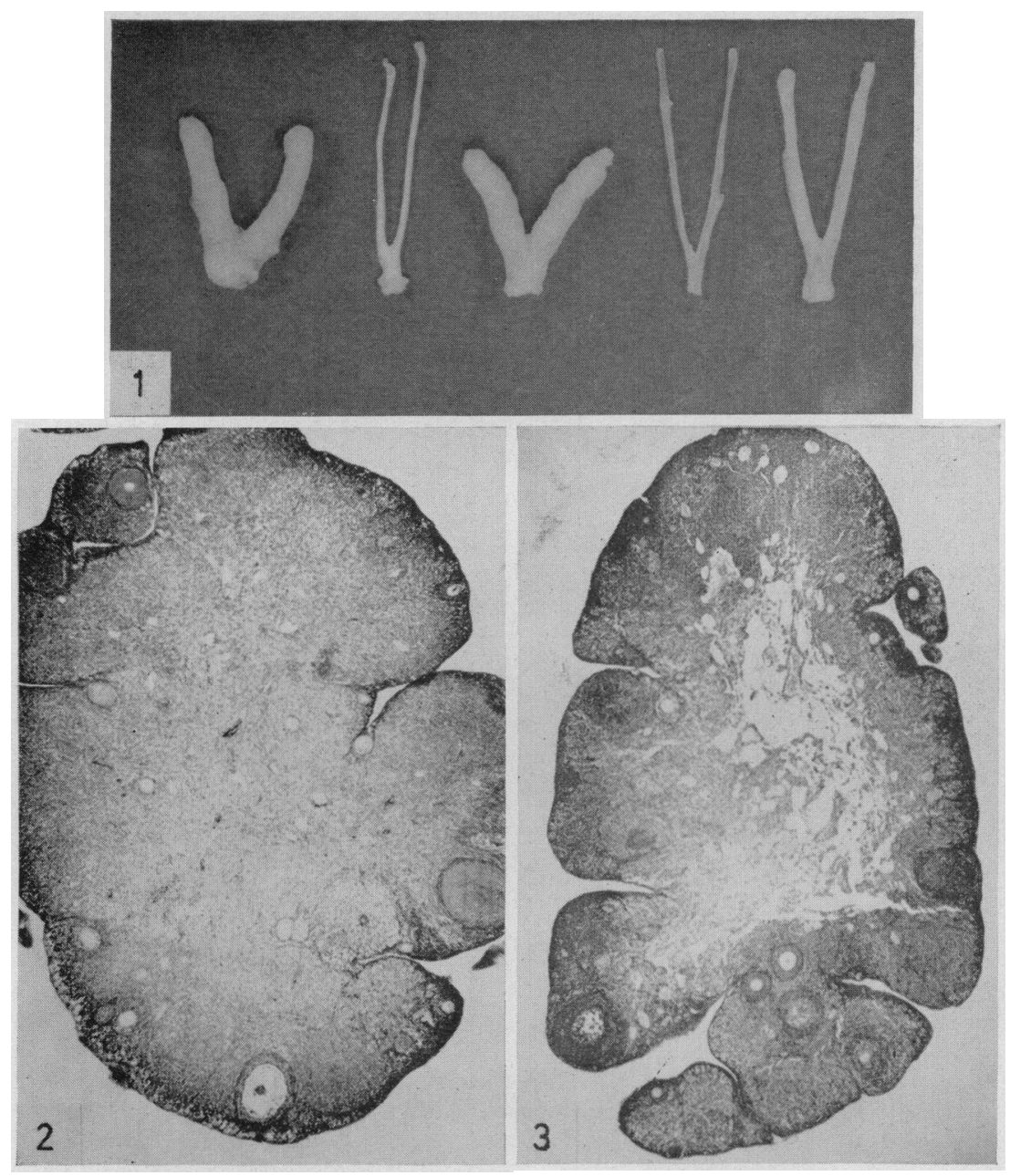

Fro. 1. Uteri from animals killed after 50 days of treatment. From left to right: a uterus from a unilaterally enucleated hamster kept at $22 \mathrm{C}$, from a blinded warm-exposed hamster, from a blinded pinealectomized hamster maintained at $22^{\prime \prime} \mathrm{C}$, from a blinded cold-exposed hamster, and from a blinded cold-exposed pinealectomized hamster.

FIG. 2. An ovary from a blinded hamster, showing a marked reduction in the number of follicles and corpora lutea. Therc has been a still more obvious increase in the amount of interstitial tissue. Owing to the small number of follicular elements and corpora lutea, which frequently bulge from the surface, the borders of these ovarics are relatively smooth (compare with PI. 2, Figs. 5 and 6).

FIG. 3. An ovary from a blinded, cold-exposed, pinealectomized hamster. The structure of the ovaries of these animals resembles that of blinded or blinded cold-exposed animals. 
PLATE 2

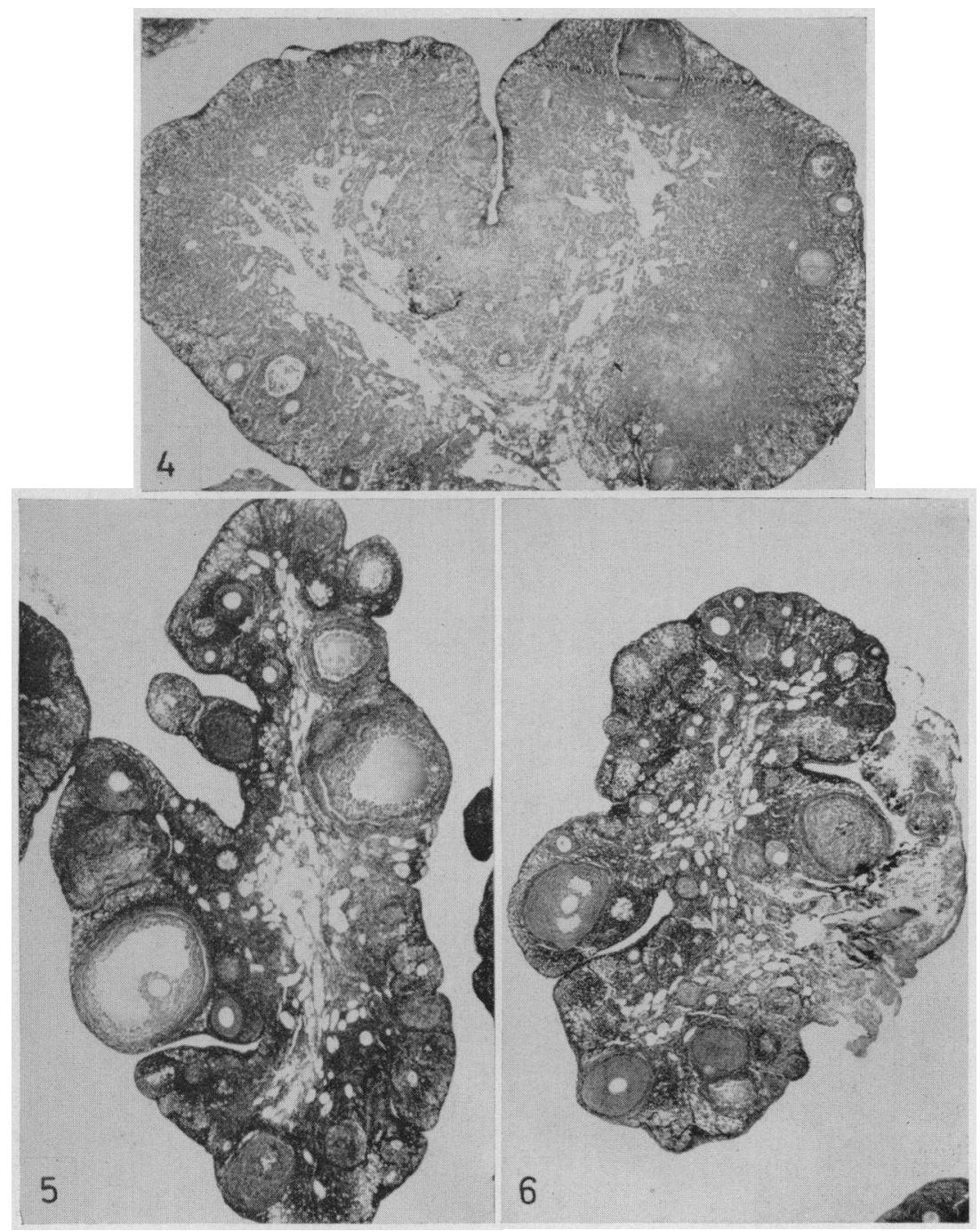

Fig. 4. Ovary from a non-pinealectomized hamster that was both blinded and coldexposed. Again, there is a hypertrophic interstitium and reduction in the number of follicular elements.

FIG. 5. An ovary of a blinded pinealectomized hamster. Ovaries from these animals were indistinguishable from those of unilaterally enucleated warm-exposed hamsters. They contained pre-antral and vesicular follicles and corpora lutea.

Frg, 6. Detailed structure of an ovary from a unilaterally enucleated hamster kept at $22^{\circ} \mathrm{C}$. Ovaries of these animals resembled those of normal animals. 
As at 25 days, the uteri exhibited the only gross changes after 50 days of treatment (Pl. 1, Fig. 1 and Table 2). Uteri of blinded animals kept at $22^{\circ} \mathrm{G}$ were markedly reduced in size (Group 3 ), a response that was prevented totally by pinealectomy (Group 4). The mean uterine weights of all cold-exposed animals (Groups 5 to 8) were lower than those of unilaterally enucleated, warm-exposed animals (Groups 1 and 2) and of blinded, pinealectomized animals kept at $22^{\circ} \mathrm{C}$ (Group 4). Uteri rarely regress below about $90 \mathrm{mg} / 100 \mathrm{~g}$ body weight (Reiter, Hoffman \& Hester, 1966a); it is therefore assumed that the size of the uteri of animals of Groups 3 and 7 represents maximum atrophy for these conditions. The uteri of cold-exposed, blinded, pinealectomized hamsters were not significantly heavier than those of blinded, cold-exposed animals with pineal glands (Groups 7).

\section{TABLE 1}

INTERAGTION OF THE PHOTOPERIOD AND TEMPERATURE IN THE REGULATION OF THE REPRODUCTIVE SYSTEMS OF FEMALE HAMSTERS KILLED AFTER 25 DAYS OF TREATMENT

\begin{tabular}{|c|c|c|c|c|}
\hline \multirow[t]{2}{*}{ Group and treatment } & \multirow{2}{*}{$\begin{array}{l}\text { No. of } \\
\text { animals }\end{array}$} & \multirow{2}{*}{$\begin{array}{c}\text { Body } \\
\text { weight } \\
(\mathrm{g})\end{array}$} & \multicolumn{2}{|c|}{$\begin{array}{l}\text { Mean organ weights } \\
\text { (mg/100 g body weight) }\end{array}$} \\
\hline & & & Ovaries & Uterus \\
\hline $\begin{array}{l}\text { 1. Unilateral enucleation; } \\
\text { sham pinealectomy; } 22^{\circ} \mathrm{C}\end{array}$ & 9 & $98 \pm 10$ & $22 \cdot 5 \pm 1 \cdot 8$ & $290 \pm 25$ \\
\hline $\begin{array}{l}\text { 2. Unilateral enucleation; } \\
\text { pinealectomy; } 22^{\circ} \mathrm{C}\end{array}$ & 9 & $101 \pm 5$ & $20 \cdot 1 \pm 1 \cdot 2$ & $311 \pm 26$ \\
\hline $\begin{array}{l}\text { 3. Bilateral enucleation; } \\
\text { sham pinealectomy; } 22^{\circ} \mathrm{C}\end{array}$ & 8 & $100 \pm 3$ & $23 \cdot 6 \pm 1 \cdot 1$ & $212 \pm 38$ \\
\hline $\begin{array}{l}\text { 4. Bilateral enucleation; } \\
\text { pinealectomy; } 22^{\circ} \mathrm{C}\end{array}$ & 10 & $96 \pm 4$ & $22 \cdot 3 \pm 1 \cdot 5$ & $286 \pm 22$ \\
\hline $\begin{array}{l}\text { 5. Unilateral enucleation; } \\
\text { sham pinealectomy; } 6^{\circ} \mathrm{C}\end{array}$ & 8 & $109 \pm 6$ & $23 \cdot 0 \pm 2 \cdot 1$ & $259 \pm 22$ \\
\hline $\begin{array}{l}\text { 6. Unilateral enucleation; } \\
\text { pinealectomy; } 6^{\circ} \mathrm{C}\end{array}$ & 8 & $105 \pm 4$ & $24 \cdot 6 \pm 1 \cdot 2$ & $258 \pm 25$ \\
\hline $\begin{array}{l}\text { 7. Bilateral enucleation; } \\
\text { sham pinealectomy; } 6^{\circ} \mathrm{C}\end{array}$ & 8 & $99 \pm 4$ & $24 \cdot 7 \pm 3 \cdot 3$ & $139 \pm 24$ \\
\hline $\begin{array}{l}\text { 8. Bilateral enucleation; } \\
\text { pinealectomy; } 6^{\circ} \mathrm{C}\end{array}$ & 10 & $102 \pm 3$ & $24 \cdot 5 \pm 2 \cdot 1$ & $212 \pm 19$ \\
\hline L.S.D.* & & 15 & $5 \cdot 2$ & 73 \\
\hline
\end{tabular}

* Least significant difference: the value by which any two means in a column must differ to be significantly different at the $95 \%$ level of probability.

Although ovarian sizes were unchanged after 50 days of treatment, there was a marked histological transformation of these organs. The ovaries of both blinded (Group 3) and cold-exposed (Groups 5 to 8 ) hamsters exhibited interstitial hypertrophy and fewer follicles (Pl. 1, Figs. 2, 3 and Pl. 2, Fig. 4). Vesicular follicles and corpora lutea were rare. In fact, the similarity of the histological structure of the ovaries of cold-exposed animals (Groups 5 to 8) and of blinded hamsters housed at $22^{\circ} \mathrm{C}$ (Group 3) gave the impression that there was a similar hormonal disequilibrium in all animals. The gonads of the other hamsters (Groups 1, 2 and 4) appeared normal (Pl. 2, Figs. 5 
and 6). The structure of the regressed uteri for the most part was unremarkable, but the height of the secretory epithelium and the number of endometrial glands were judged to be lower than in normal organs, although no measurements were made.

TABLE 2

INTERACTION OF THE PHOTOPERIOD AND TEMPERATURE IN THE REGULATION OF THE REPRODUCTIVE SYSTEMS OF FEMALE HAMSTERS KILLED AFTER 50 DAYS OF TREATMENT

\begin{tabular}{|c|c|c|c|c|}
\hline \multirow[t]{2}{*}{ Group and treatment } & \multirow{2}{*}{$\begin{array}{l}\text { No. of } \\
\text { animals }\end{array}$} & \multirow{2}{*}{$\begin{array}{c}\text { Body } \\
\text { weight } \\
(\mathrm{g})\end{array}$} & \multicolumn{2}{|c|}{$\begin{array}{l}\text { Mean organ weights } \\
\text { (mg/100 g body weight) }\end{array}$} \\
\hline & & & Ovaries & Uterus \\
\hline $\begin{array}{l}\text { 1. Unilateral enucleation; } \\
\text { sham pinealectomy; } 22^{\circ} \mathrm{C}\end{array}$ & 12 & $115 \pm 9$ & $20 \cdot 9 \pm 1 \cdot 6$ & $281 \pm 25$ \\
\hline $\begin{array}{l}\text { 2. Unilateral enucleation; } \\
\text { pinealectomy; } 22^{\circ} \mathrm{C}\end{array}$ & 15 & $124 \pm 11$ & $19 \cdot 3 \pm 0.9$ & $276 \pm 19$ \\
\hline $\begin{array}{l}\text { 3. Bilateral enucleation; } \\
\text { sham pinealectomy; } 22^{\circ} \mathrm{C}\end{array}$ & 9 & $115 \pm 8$ & $19 \cdot 0 \pm 2 \cdot 2$ & $90 \pm 8$ \\
\hline $\begin{array}{l}\text { 4. Bilateral enucleation; } \\
\text { pinealectomy; } 22^{\circ} \mathrm{C}\end{array}$ & 8 & $105 \pm 9$ & $22 \cdot 2 \pm 1 \cdot 6$ & $281 \pm 29$ \\
\hline 5. Unilateral enucleation; & 12 & $109 \pm 5$ & $21 \cdot 7 \pm 2 \cdot 3$ & $168 \pm 27$ \\
\hline $\begin{array}{l}\text { 6. Unilateral enucleation; } \\
\text { pinealectomy; } 6^{\circ} \mathrm{C}\end{array}$ & 8 & $129 \pm 8$ & $19 \cdot 9 \pm 1 \cdot 6$ & $178 \pm 29$ \\
\hline $\begin{array}{l}\text { 7. Bilateral enucleation; } \\
\text { sham pinealectomy; } 6^{\circ} \mathrm{C}\end{array}$ & 13 & $127 \pm 12$ & $21 \cdot 3 \pm 1 \cdot 7$ & $96 \pm 11$ \\
\hline $\begin{array}{l}\text { 8. Bilateral enucleation; } \\
\text { pinealectomy; } 6^{\circ} \mathrm{C}\end{array}$ & 8 & $105 \pm 9$ & $21 \cdot 7 \pm 1 \cdot 7$ & $138 \pm 9$ \\
\hline L.S.D.* & & 26 & $5 \cdot 1$ & 65 \\
\hline
\end{tabular}

* Least significant difference: the value by which any two means in a column must differ to be significantly different at the $95 \%$ level of probability.

\section{DISCUSSION}

It has been stated that hibernation is incompatible with an active reproductive system (Kayser, 1957; Hoffman, 1964). In support of this conclusion Foster, Foster \& Meyer (1939) reported that the tendency of the thirteen-lined ground squirrel to hibernate is inversely related to genital activity. Evidently, involuted, or at least modified, reproductive organs are needed for successful entrance into hibernation. The experiments of Hoffman et al. (1965) on male hamsters and those reported here on females show that both light-deprivation and coldexposure, either alone or in combination, can cause gonadal regression and that, when hamsters are exposed to both, the effects on the gonads are additive. This latter finding also agrees with the observations of Hoffman et al. (1965) on male hamsters.

The structure of the atrophic ovaries from both cold-exposed and blinded hamsters was similar. The most important features of the involuted gonads were the reduction in the number of antral follicles and corpora lutea and the hypertrophy of the interstitium. The structural character of the altered organs 
suggests that a similar hormonal imbalance existed in animals under both conditions. This, however, does not imply that the mechanisms of gonadal involution were the same in both cases. In fact, it is quite obvious that they were different since removal of the pineal gland prevented gonadal regression in blinded hamsters whereas it had no effect on these processes in cold-exposed animals. The absence of a change in ovarian sizes in blinded and cold-exposed hamsters despite a profound decline in uterine weights emphasizes the point which Reiter et al. (1966a) made earlier that, in the hamster, ovarian weights are a poor indicator of the secretory activity of the organ.

The mechanisms whereby light-deprivation or cold-exposure alters gonad function remain unknown. The atrophic reproductive organs of blinded female hamsters respond to the exogenous administration of follicle-stimulating hormone (FSH) and luteinizing hormone (LH) (Reiter, 1967b). It has been suggested that the pineal gland, activated by the absence of light, alters the central control of either the synthesis or release of pituitary gonadotrophins (Reiter \& Hester, 1966). Perhaps both blinding and low environmental temperature influence reproduction by modifying the neuroendocrine axis rather than by a direct effect on the action of the hormones on the target organs.

Homeothermic poly-oestrous animals such as the rat and mouse exhibit moderate changes in their reproductive cycles when exposed to cold. Rats exposed to cold and provided with $12 \mathrm{hr}$ of illumination per 24-hr period exhibit prolonged pro-oestrous and oestrous phases of the vaginal cycle (Denison $\&$ Zarrow, 1955). Since mice reproduce when kept at subzero temperatures $\left(-3^{\circ} \mathrm{C}\right)$ the reproductive organs do not regress under conditions of low environmental temperature (Barnett, 1956; Barnett \& Manly, 1959); in both these studies the lights were on $12 \mathrm{hr} /$ day. Golden hamsters kept in a room at $7.5^{\circ} \mathrm{C}$, with $12 \mathrm{hr}$ of light/day, often have anoestrous vaginal smears (Grindeland \& Folk, 1962). Some of these animals had normal 4-day vaginal cycles after removal from the cold. Although vaginal smears were not taken, the animals with atrophic ovaries and uteri were probably in an anoestrous state. The profound effects of low temperature and blinding on the reproductive physiology of the heterothermic golden hamster, which are in contrast to their effects on non-hibernators such as rats and mice, may be related to the ability to hibernate.

\section{ACKNOWLEDGMENTS}

Supported in part by General Research Support Grant (United States Public Health Service) and in part by Grant HD-02937-01, United States Public Health Service.

\section{REFERENCES}

Baillie, A. H. (1961) Histochemical studies of the mouse testis following cold exposure. Scott. med. $\mathcal{F}$. 6,6 .

BARNETt, S. A. (1956) Endothermy and ectothermy in mice at $-3^{\circ} \mathrm{C}$. F. $\exp$. Biol. 33, 124.

BARNETT, S. A. \& MANLY, B. M. (1959) Effects of low environmental temperature on the breeding performance of mice. Proc. R. Soc. B, 151, 87.

Browman, L. G. (1937) Light in its relation to activity and estrous rhythms in the albino rat. 7. exp. Zool. 75, 375 . 
Densson, M. E. \& Zarrow, M. X. (1955) Changes in the estrous cycle of rats during prolonged exposure to cold. Proc. Soc. exp. Biol. Med. 89, 632.

Eisentraut, M. (1952) Beobachtungen über den Winterschlaf der Hamster, insbesondere des Goldhamster (Mesocricetus auratus Waterhouse). Zool. Anz. 149, 115.

Ewing, L. L., Brant, G. \& Ebner, K. E. (1967) The effects of chronic cold stress on the metabolism and chemical constituents of the mature rat testis. F. Reprod. Fert. 13, 213.

Foster, M. S., Foster, R. G. \& Meyer, R. K. (1939) Hibernation and the endocrines. Endocrinology, 24, 603 .

Grindeland, R. E. \& Folk, G. E. (1962) Eiferts of cold exposure on the oestrous cycle of the golden hamster (Mesocricetus auratus). F. Reprod. Fert. 4, 1.

HAFEz, E. S. E. (1964) Environment and reproducti $n$ in domesticated species. Int. Rev. gen. E exp. Zoul. 1, 113.

Hale, H. B., Mefrerd, R. B., JR, Vowter, G., Forrster, E. G. \& Griscuolo, D. (1959) Influence of long-term exposure to adverse environments on organ weights and histology. Am. J. Physiol. $196,520$.

Hoffmann, J. C. (1967) Effects of light deprivation on the rat estrous cycle. Neuruendocrinology, 2, 1.

Hoffman, R. A. (1964), Speculations on the regulation of hibernation. Suomal. Tiedeakat. Toim. Sarja IV. Biologica, 71, 201.

Hoffman, R. A., Hester, R. J. \& Towns, C. (1965) Effect of light and temperature on the endocrine system of the golder namster (Mesocricetus auratus Waterhouse). Comp. Biochem. Physiol. 15, 525.

Hoffman, R. A. \& ReIter, P. j. (1965a) Pineal gland: Influence on gonads of male namsters. sczence, $\mathcal{N} . r .148,1609$.

Hoffman, R. A. \& Reiter, R. J. (1965b) Rapid pinealectomy in hamsters and other small animals. Anat. Rec. 153, 19.

KAYser, G. (1957) Le sommeil hivernal, probléme de thermorégulation. Revue can. Biol. 16. 303.

Kent, G. C., JR (1967) Physiology of reproduction. In: The Golden Hamster: Its Biology and Use in Medical Research, p. 119. Eds. R. A. Hoffman, P. F. Robinson and H. Magalhaes. Iowa State University Press, Ames.

Lyman, G. P. (1948) The oxygen consumption and temperature regulation of hibernating hamsters. 7. exp. Zool. 109, 55.

Lyman, G. P. \& Chatfield, P. O. (1955) Physiology of hibernation in mammals. Physiol. Rev. 35, 403.

Movat, H. Z. (1955) Demonstration of all connective tissue elements in a single section. Archs Path. $55,289$.

Reiter, R. J. (1967a) The effects of pineal grafts, pinealectomy, and denervation of the pineal gland on the reproductive organs of male hamsters. Neuroendocrinology, 2, 138.

REITER, R. J. (1967b) Failure of the pineal gland to prevent gonadotrophin-induced ovarian stimulation in blinded hamsters. F. Endocr. 38, 199.

Reiter, R. J. \& Hester, R. J. (1966) Interrelationships of the pineal gland, the superior cervical ganglia and the photoperiod in the regulation of the endocrine systems of hamsters. Endocrino$\log y, 79,1168$.

Reiter, R. J., Hoffman, R. A. \& Hester, R. J. (1966a) The effects of thiourea, photoperiod and the pineal gland on the thyroid, adrenal and reproductive organs of female hamsters. F. exp. Zool. $162,263$.

Reiter, R. J., Hoffman, R. A. \& Hester, R. J. (1966b) The role of the pineal gland and of environmental lighting in the regulation of the endocrine and reproductive systems of rodents. Edgewood Arsenal Technical Report No. 4032, Medical Research Laboratory, U.S. Army Edgewood Arsenal, Maryland. 